West German health care reform hazards pharmaceutical research

\section{Munich}

THE West German pharmaceutical industry is protesting against a proposed reform in West Germany's national health insurance programme. The proposal, introduced by the government on 3 December, calls for a two-thirds reduction in the amount that public health insurers, or Krankenkassen, will pay for drugs.

Drug manufacturer Hoechst denounced the reform as a "death blow" to pharmaceutical research, while rival Bayer predicted that the reform would lead to the "structural collapse" -of West German drug research.

Labour Minister Norbert Blüm's (Christian Democrat) reform proposal is an attempt by the ruling conservative coalition to slow galloping increases in health care costs. Under the mandatory public health insurance system, half the premiums are paid by employers and half by employees. These premiums increased in 1987 to 12.7 per cent of the average worker's income, compared with 8.2 per cent in 1970 . If costs were to rise unchecked, employer and employee would be paying 20 per cent of gross income for health insurance by the year 2000 .

\section{Directorship for Roy Woodruff}

\section{San Francisco}

Roy D. Woodruff, the Lawrence Livermore National Laboratory (LLNL) physicist who accused Edward Teller and Lowell Wood of misrepresenting the progress of $\mathrm{X}$-ray laser research, has been appointed director of weapons verification research at $\mathrm{LLNL}$.

Woodruff resigned as director of the $\mathrm{X}$ ray laser programme in $\mathbf{1 9 8 5}$ following his disagreement with Wood and Teller about their "overly optimistic" presentation of the programme to officials in Washington (see Nature 329, 751; 1987). He later filed a grievance with the University of California, which oversees the laboratory, claiming he had been demoted as punishment for his views.

In October, the university ordered the laboratory to reinstate Woodruff in a position that would make appropriate use of his skills.

George H. Miller, associate director for defence systems, said that he created Woodruff's new position of assistant associate director for verification because he expects verification to play an increasingly important role in arms control and weapons design issues, both at the laboratory and in Washington. Marcia Barinaga
Under the reform plan, the insurers would realize an annual saving of DM14,300 million beginning in 1989. Part of the money would derive from the reduction in drug costs and part of it from a reduction in a variety of benefits. DM6,500 million would go into a new home care programme for the severely disabled, DM500 million to the detection and prevention of cancer and other diseases, and the rest would be returned in the form of reduced premiums.

Under Blüm's plan, public insurers would pay only a certain amount for prescriptions. The amount would be fixed somewhere in the lower third of the price spread. The patient would have to pay the difference for a higher-priced drug, that is, a brand-name drug patented by a drug company, with the same effects.

Such wholesale support for generic drugs is unrealistic, the drug companies have replied, given the costs of research. Development of a single synthetic anti- biotic cost Bayer DM330 million, said Hermann Strenger, chairman of the Bayer board. Bayer patented aspirin in the late 1890 s. Blüm also called for the pharmaceutical industry to show "solidarity" by freezing prices at current levels in addition to pricing their drugs more competitively. This demand is equally galling to the drug companies, which claim to have "already done their part" by keeping prices stable over the last several years, said Helga Hennemann of Hoechst.

The drug companies complain that Blüm's reform will cost them DM 3,700 million annually, a reduction of 40 per cent in the amount they normally receive from the Krankenkassen. Blüm places the figure at DM2,500 million.

Bayer, Hoechst and their West German rivals feel threatened by US and Japanese competition in the area of drug development. But it will be hard to assess the real effects of Blüm's reform on the companies' research budgets. At Bayer, for example, the pharmaceuticals division accounts for only 15 per cent of annual sales. The companies have until the end of 1988 to try to sway the Bundestag before Blüm's plan is made law. Steven Dickman

\title{
UK under fire for refusal to increase ESA science budget
}

\section{London}

THE British government's insistence that the science budget of the European Space Agency (ESA) be frozen after 1989 is causing growing resentment among space scientists at home and abroad. At ESA's ministerial meeting in The Hague last month (see Nature 330, 195; 1987), Britain was the only member state to veto previously agreed increases in the budget of the Horizon 2000 science programme. Because the science budget forms part of the mandatory subscription, its acceptance requires unanimous agreement.

This week saw the start of the familiar and usually fruitless task of persuading Britain to toe the international line, with the most vociferous campaigning coming from Britain's own space community, facing ever-increasing international isolation.

Horizon 2000, announced in 1984 , was seen as a pioneering move that encouraged unprecedented unity and cooperation among Europe's space scientists. At The Hague, Britain argued that over the current five years the 27 per cent increase in real terms in the programme's budget ought not be added to, and that the programme's projected duration should instead be increased. This, argued Britain, would neither "destroy the programme nor make the intervals between missions too long".

It had originally been intended that the
1988 budget of 176.8 MAU (million accounting units; $1 \mathrm{AU}=£ 0.64$ ) be increased annually by 5 per cent to a ceiling of 232.3 MAU by 1994. Supporters say that Britain's stance will substantially damage the programme: plans had been drawn up around precisely calculated funding levels and a simple extension of the programme's life would not only be ultimately more expensive, but would disrupt the entire timetable.

A final decision on the shape of the science programme will be taken next Spring. ESA officials have until then to change the British government's mind. They are not hopeful. Simon Hadlington

\section{Soviet psychiatry}

\section{London}

THE United States Department of Health and Human Services has turned down a proposal from the Soviet Union for a joint commission of Soviet and American psychiatrists to look into allegations of the political misuse of psychiatry in the Soviet Union. Speaking on Soviet television last month, Academician Evgenii Chazov, the Soviet Minister of Health, said the head of the foreign relations administration of the US Health Department had replied that US psychiatrists are not interested in Soviet psychiatry, and would therefore not take part in any such commission. Vera Rich 